\title{
BLIND IN THEIR OWN CAUSE: THE MILITARY COURTS IN THE WEST BANK
}

\author{
Yaël Ronen ${ }^{*}$
}

\begin{abstract}
The military courts operating in the West Bank do not ordinarily regard the criminal system they enforce as governed by the law of occupation. Their reasoning for this view reveals that they perceive themselves as quasi-domestic courts. This approach removes the guarantee of basic protection for protected persons under the law of occupation, leaving suspects and defendants hostage to potential vagaries of the military commander in enacting the security legislation. The courts' responses to this shortfall in protection are principally that in practice, many of the international standards have been incorporated into the law applied in the military courts by duplication of Israeli law, and that Israel's High Court of Justice offers means of ensuring compliance of the criminal process with international law. Both responses further reflect the courts' abdication of their role in guaranteeing legal protection under the law of occupation.
\end{abstract}

\section{Keywords}

Military courts, law of occupation, monism, dualism, Israel

\section{Introduction}

Immediately upon the assumption of governmental authority in the West Bank in 1967, Israel established military courts in the West Bank and the Gaza Strip. On 7 June the military commander of the Israeli Defence Forces in the West Bank (the 'military commander') issued Proclamation No 3, to which was annexed the Security Provisions Order (West Bank region) 1967. ${ }^{1}$ The Security Provisions Order (SPO) came into force immediately. It authorized the military commander to establish military courts, stipulated their rules of procedure, and set out a list of

\footnotetext{
* Senior Lecturer, Sha'arei Mishpat Law School, Israel. This article is based, inter alia, on lengthy interviews with present and former judges of the military courts, to whom I am indebted for sharing their perspective and views. I am also grateful to Smadar Ben-Natan, Henri Decoeur, Shai Dothan, Aeyal Gross, David Kretzmer and Yuval Shany for their helpful comments on earlier versions of the manuscript and to Yael Naggan for excellent assistance. The views expressed are solely my own. <yael.ronen@mail.huji.ac.il>.

1 Compilation of Proclamations, Orders and Appointments of the IDF Command in the West Bank Area No 1(1967), 5.
}

Copyright $\odot$ the Author(s).

This work is licensed under a Creative Commons Attribution-NonCommercial-NoDerivs 3.0 License. 
offences punishable by these courts. ${ }^{2}$ On the same day, the military commander ordered the establishment of military courts. ${ }^{3}$ Over the past 46 years these courts have issued hundreds of thousands of judgments and other decisions. ${ }^{4}$

Prior to the Israeli occupation, the most recent experience in maintaining a military court system by an occupant was in Germany, in the aftermath of the Second World War. The Fourth Geneva Convention (GC IV) ${ }^{5}$ had not yet been adopted; the only controlling norms were the Hague Regulations, which do not regulate the criminal process. ${ }^{6}$ Nor did pertinent international human rights law exist at the time. Instead, the US military government for Germany issued a directive on the fundamental principles to be adhered to in military government courts, according to which it was 'desired that Military Government Court proceedings in all essential points conform to the traditional procedures

2 Security Provisions Order (Judea and Samaria) 1967, Art 5, section B and section C respectively.

3 Order regarding Establishment of Military courts (West Bank Area) (No 3) 1967, 7 June 1967, Compilation of Proclamations, Orders and Appointments No 1, 25. On the establishment of the military courts, their constitution, jurisdiction, and rules of procedure and evidence (as of 1980) see Z Hadar, 'The Military Courts', in M Shamgar (ed), Military Government in the Territories Administered by Israel 1967-1980, vol 1 (1982), 171.

4 According to the annual activity reports of the Military Advocate General (MAG), since 1990 alone over 150,000 individuals have been tried; see N Benichou, 'On Criminal Law in Judea, Samaria and Gaza Areas: A Window and Trends' (2005) 18 Army and Law 293, 294 [in Hebrew]; Yesh Din, Backyard Proceedings: The Implementation of Due Process Rights in the Military Courts in the Occupied Territories (2007) <http://www.yesh-din.org/site/im ages/BackyardProceedingsEng.pdf> [accessed 04 May 2013]; for 2004-2006, Military Advocate General Corps, Activity Report for the Year 2007 [in Hebrew] <http://www.law.idf.il/sip_stor age//FILES/3/393.pdf textgreater [accessed 04 May 2013]; Military Advocate General Corps, Activity Report for the Year 2008 [in Hebrew] <http://www.law.idf.il/sip_storage//FILES/4/394.pdf textgreater [accessed 29 August 2013]; Military Advocate General Corps, Activity Report for the Year 2009 [in Hebrew] <http://www.law.idf.il/sip_storage//FILES/0/750.pdf textgreater [accessed 29 August 2013]; Military Advocate General Corps, Activity Report for the Year 2010 [in Hebrew] <http://www.law.idf.il/sip_storage//FILES/7/967.pdf textgreater [accessed 29 August 2013]; Military Advocate General Corps, Activity Report for the Year 2010 [in Hebrew] <http://www.law.idf.il/sip_storage//FILES/7/967.pdf textgreater [accessed $29 \mathrm{Au}-$ gust 2013]; Military Advocate General Corps, Activity Report for the Year 2011 [in Hebrew] <http://www.law.idf.il/sip_storage//FILES/9/1209.pdf textgreater [accessed $29 \mathrm{Au}-$ gust 2013]; Military Advocate General Corps, Activity Report for the Year 2012 [in Hebrew] <http://www.mag.idf.il/SIP_STORAGE/FILES/4/1394.pdf textgreater [accessed $29 \mathrm{Au}-$ gust 2013]; the military courts in the Gaza Strip were closed down when Israel disengaged from the territory in 2005.

5 Geneva Convention Relative to the Protection of Civilian Persons in Time of War, 12 August 1949, 75 UNTS 287 (GC IV).

6 Convention (IV) Respecting the Laws and Customs of War on Land and its Annex: Regulation concerning the Laws and Customs of War on Land, 18 October 1907, 187 CTS 227. 
of American law ... [and] respect the guaranties of personal rights provided by German Constitutions.' As a result, the Israeli military courts have been the first to discuss the applicability of international law to a military court system and their jurisprudence is unprecedented.

This article explores the applicability and enforcement of the international law of occupation with respect to the criminal process in the military courts. It demonstrates that the courts address the matter from the perspective of courts acting within a domestic legal order, despite the fact that they draw their authority from international law. This gap undermines the application of international law and deprives defendants of the legal protection of the law of occupation.

Section 2 discusses different approaches to the relationship between international and domestic law and explains how these play out under occupation. Section 3 provides a brief description of the military court system and examines the practice of the courts. Section 4 describes the military courts' perception of the legal order within which they operate and their consequent refusal to apply the law of occupation. Section 5 examines the responses to the critique that this refusal has elicited and demonstrates that these responses are themselves predicated on the self-perception of the courts as domestic ones. This section also demonstrates the ensuing shortfall in protection. The final section of this paper draws conclusions on the unique character of Israeli military courts.

\section{The occupation legal order and the international legal order}

The relationship between a domestic legal order and the international one is often described through the distinction between monism and dualism. In brief, monism suggests that national and international law are part of a single system of law, in which international rules trump national ones. Dualism, on the other hand, considers national and international law as different legal systems; it maintains that international rules can only enter the domestic legal system by being transformed into domestic rules. ${ }^{8}$ These are explanatory theories that are of little relevance from an international legal perspective, where international law

\footnotetext{
Office of Military Government for Germany (US) Official Statement of Principles (16 July 1947), cited in E E Nobleman, 'American Military Government Courts in Germany', The Annals of the American Academy of Political and Social Science (1950) 87, 91.

8 M N Shaw, International Law (6 ${ }^{\text {th }}$ edn 2008) 131-133.
} 
holds primacy over domestic law. ${ }^{9}$ Adherence to a monist theory supports this primacy; yet even a dualist theory does not invalidate it, since failure to observe an international rule incurs international responsibility. International law does not prescribe one theory or the other. All things being equal, ${ }^{10}$ however, a monist system better facilitates compliance with international law, because international law holds normative superiority within it. Under a dualist approach, on the other hand, compliance may depend on ex post facto international enforcement in case of violation of an international rule.

In democratic states, dualism is justified as a preservation of the separation of powers: while the executive negotiates treaties, the legislature has the last word on their application within the domestic order. This justification is inapplicable to a regime of occupation, where both executive and legislative powers are vested in the military commander. Moreover, unlike a democratic state's constituency, which may forfeit the protection of international law in the first instance and delegate the power to enforce it to external institutions, the population of an occupied territory cannot be deemed to have voluntarily made such a choice. Such considerations invite the conclusion that monism should prevail de lege ferenda. De lege lata, however, international law is silent on how it should be integrated into a regime of occupation.

Israel has adopted a monist approach insofar as concerns its actions as an occupant. The preambles of Proclamations Nos 2 and 3 state that they are promulgated 'in order to ensure proper governance and to maintain safety and public order', evoking Hague Regulations Article 43. ${ }^{11}$ Proclamation No 2, stating the law applicable in the territory, preserves existing law (subject to military enactments) as required by the law of occupation. ${ }^{12}$ Most importantly, Article 35 of the SPO originally provided that

a military court and its administration shall follow the provisions of the Geneva Convention of 12 August 1949 relating to the Protection

\footnotetext{
${ }_{9}$ Eg Vienna Convention on the Law of Treaties, 23 May 1969, 1155 UNTS 331, Art 27. This is not strictly a monist approach, since it does not necessarily imply that the source of domestic law is international law but merely that the latter takes precedence over the former.

${ }^{10}$ They rarely are. It would be incorrect to assume that in practice states leaning towards monism comply with international law more than those which are more dualist.

${ }^{11}$ Proclamation No 2 regarding Governance and Law Arrangements and Proclamation No 3 regarding Entry into Force of the Provisions of Security Order, 7 June 1967, Compilation of Proclamations, Orders and Appointments of the IDF Command in the West Bank Area No 1 (11 August 1967) 3-5.

${ }^{12}$ Ibid, s 2.
} 
of Civilians in War insofar as concerns judicial proceedings, and where this Order conflicts with the said Convention, the provisions of the Convention shall prevail.

Article 43 of the Hague Regulations has been cited by military courts at an early stage as enjoining the military commander to ensure public order and safety in occupied territory including by the establishment of military courts. ${ }^{13}$ The same approach, namely that the military government derives its legal authority directly from international law and specifically the law of occupation, was declared by the Israeli Supreme Court sitting as High Court of Justice (HCJ). ${ }^{14}$ At the same time, Israel has from an early stage denied the de jure applicability of GC IV on the ground that the preceding regimes in the West Bank (including East Jerusalem) and the Gaza Strip had not been sovereign ones, ${ }^{15}$ although it undertook to comply with the humanitarian provisions of the Convention.

GC IV Article 64 allows the occupant to subject the population of the occupied territory to penal provisions which are essential for enabling the occupant to fulfil its obligations under the Convention, to maintain the orderly government of the territory, and to ensure the security of the occupant, its members and property. This can be done through establishment of military courts, for which GC IV sets certain parameters. The Convention was drafted at a time when international human rights law was in its infancy, and the applicability of this body of law extraterritorially and to enemy nationals was unthinkable. Yet GC IV reflects the understanding that enemy nationals are particularly vulnerable to mistreatment, and are thus in need of special protection, including in military courts which are an organ of the military government. ${ }^{16}$ The Convention therefore provides fundamental guarantees of fair trial and physical integrity. Article 66 stipulates that military courts should be properly constituted and non political, and must sit in the occupied territory. Articles 67-77 provide minimum guarantees of fair trial and treatment of detainees and defendants. The occupant's

${ }^{13}$ Military Prosecutor v Abu Janem, Gaza 1238/69 Selected Judgments of the Military Courts vol 1 (1969) 130, 140.

${ }^{14}$ Abu Itta and Others $v$ Commander of IDF Forces in the West Bank and Others, HCJ 69/81 PD 37(2) 197, 228, 301 (1983); Jamait Iscan v IDF Commander in Judea and Samaria, (1983) HCJ 393/82 PD 37(4) 785, para 23.

${ }^{15}$ Y Z Blum, 'The Missing Reversioner: Reflections on the Status of Judea and Samaria' (1968) 3 Israel L Rev 279.

${ }^{16}$ It has been contested whether civilians may serve as judges in military courts; G von Glahn, The Occupation of Enemy Territory: A Commentary on the Law and Practice of Belligerent Occupation (1957) 116. 
authority to ensure orderly government is further constrained by international human rights law insofar as it is applicable in occupied territory. Military courts are therefore both empowered by international law and function as its guardians.

\section{The military courts: background}

The Israeli military courts operate under the terms of the SPO, amended over a hundred times since $1967,{ }^{17}$ and complemented through numerous additional orders on specific issues. Like all military enactments, the SPO was drafted by the Military Advocate General (MAG) and was put into force by the military commander, who is the highest legislative and executive instance within the military government.

Two courts of first instance operate in the West Bank, ${ }^{18}$ as well as a Military Court of Appeal. ${ }^{19}$ In 2009 a military court of first instance for youth was established with jurisdiction over defendants under the age of sixteen, the rulings of which may be appealed in the Military Court of Appeal. ${ }^{20}$ The courts sit in single judge or three judge formations. Since 2003 all judges are trained lawyers. ${ }^{21}$ At the time of writing there are eighteen military career judges serving in the courts of first instance, and four military career judges in the Court of Appeal. In addition there are reserve service judges in both instances.

The jurisdiction ratione materiae of the courts is stipulated in the SPO as encompassing any offence defined by enactments of the military commander (referred to as the 'security legislation') and any offence under Jordanian law. ${ }^{22}$ Broadly speaking, the security legislation establishes offences of two categories: acts which jeopardize military interests or the safety of the territory, ordinarily

\footnotetext{
${ }^{17}$ The numerous amendments have twice been incorporated into consolidated versions. First in 1970, in the Security Provisions Order (Judea and Samaria) No 378, 1970, Compilation of Proclamations, Orders and Appointments No 21, 33, and again in the Order presently in force, the Security Provisions Order [Consolidated Version] (Order No 1651) of 2009 (2009 SPO). Since 2009 , this recent Order has already been amended over two dozen times.

${ }^{18}$ The military commander originally established five courts for the West Bank and Jerusalem area; Order regarding Establishment of Military courts, above n 3. The number of first instance courts has varied through the years in light of changing circumstances.

${ }^{19}$ Security Provisions Order (Amendment No 58) (Judea and Samaria) (No 1265), 5749-1989.

${ }^{20} 2009$ SPO, Arts 135-149, previously Security Provisions Order (Temporary Provision) (Amendment 109) (No 1644) 29 July 2009.

${ }^{21} 2009$ SPO, Arts 16, 17, 19.

${ }^{22}$ Ibid, Art 10(a), previously 1967 SPO Art 8 and Military Order regarding Jurisdiction in Criminal offences (No 30) 1967 Art 2.
} 
referred to as 'security offences' (encompassing a range of conducts, from use of firearms to unauthorized exit from the West Bank into Israel); and acts which jeopardize public order within the meaning of Hague Regulations Article 43 (such as violations of licensing provisions and traffic regulations). ${ }^{23}$ Jordanian law is applied in the case of ordinary crimes. ${ }^{24}$ The military courts also exercise judicial review over administrative orders issued by the military commander against individuals relating to administrative detention, ${ }^{25}$ restriction, ${ }^{26}$ surveillance and assigned residence, ${ }^{27}$ and deportation. ${ }^{28}$

The SPO makes no qualifications as to the jurisdiction of the military court ratione personae. Historically, military courts were intended to try the local population of the occupied territory, but the military courts in the West Bank and Gaza Strip have interpreted the SPO as also empowering them to try Israeli nationals and residents when those are charged with offences committed in the occupied territories. ${ }^{29}$ Nonetheless, since the early 1980s the Attorney-General's policy has been to prosecute Israeli nationals and residents, including those actually residing in the occupied territory, before Israeli courts. ${ }^{30}$ Review of all administrative orders by the military commander remains in the hands of the military courts, even when issued against Israelis. Under the Interim Agreement concluded by Israel and the PLO in 1995, offences committed by Palestinians in Area A and B were largely excluded from the jurisdiction of the military courts. ${ }^{31}$ Nevertheless, the SPO preserves the military courts' jurisdiction over all acts which harm or are intended to harm the security of the West Bank, irrespective

${ }^{23}$ Hadar, above $\mathrm{n} 3,187$. Traffic violations constitute some $40 \%$ of indictments.

${ }^{24}$ Ordinary crimes are estimated at $7-8 \%$ of indictments. For detailed analysis of the security legislation as of 1975 see M Drori, The Legislation in the Area of Judea and Samaria (1975).

252009 SPO, Arts 275, 278

${ }^{26}$ Ibid, Art 296(c), sitting as an appeals commission.

${ }^{27}$ Ibid, Art 297(e), sitting as an appeals commission.

${ }^{28}$ Ibid, Arts 307-310, sitting as the Commission to Examine Deportation Orders.

${ }^{29}$ Military Prosecutor $v$ Abu Janem, above n 13, 135-136

${ }^{30}$ IDF spokesperson, cited in Yesh Din, above $n$ 4, 59. The jurisdiction of Israeli courts is provided for in Emergency Regulations (Judea and Samaria and the Gaza Strip-Jurisdiction in Offences and Legal Assistance) 1967, s 2(a), as extended by the Law for the Extension of Validity of the Emergency Regulations (Judea and the Samaria-Jurisdiction in Offences and Legal Assistance) 2012.

${ }^{31}$ Israeli-Palestinian Interim Agreement on the West Bank and the Gaza Strip, 28 September 1995, 36 ILM 557, Annex IV Article I. In Area A, the Palestinians exercise powers and responsibilities for internal security and public order as well as for civil affairs; ibid Annex I. In area B they exercise powers and responsibilities for public order and civil affairs; ibid Annex III. 
of where precisely within the West Bank they were committed. ${ }^{32}$

Under the security legislation, the Military Court of Appeal is the highest judicial instance. However, under Israeli jurisprudence, all governmental organs, including the military government in the occupied territory, are subject to Israeli administrative law. ${ }^{33}$ In accordance with an instruction of the Attorney-General, issued shortly after the occupation of the West Bank and Gaza Strip, Palestinians resident in those areas may appeal to the Israeli Supreme Court sitting as High Court of Justice. On this basis tens of thousands of Palestinians have petitioned the HCJ against military authorities' actions and decisions, ${ }^{34}$ including by the military courts.

The SPO stipulates the fundamental substantive criminal provisions, procedure and laws of evidence applicable in the military courts. It also provides for residual sources of law: in procedural matters not regulated by the SPO, first instance courts may adopt measures that appear to them 'most suitable in order to do justice, ${ }^{35}$ while the Military Court of Appeal follows the procedure of the Israeli Defence Force (IDF) courts martial. ${ }^{36}$ In matters of evidence the SPO provides that the courts should follow "binding rules in criminal matters in courts of the State of Israel.'37

The legal instruments establishing the courts and regulating their operation do not mention international law explicitly. SPO Article 35, mentioned above, was replaced at the end of 1967 by a provision concerning the calculation of a period of detention within a convicted person's sentence. ${ }^{38}$ This provision had nothing to do with the original content of Article 35, nor, for that matter, with the surrounding articles, but it did obfuscate the obliteration of any reference to GC IV. At around the same time as Article 35 was replaced, various other provisions of the SPO were amended, apparently in order to comply with substantive provisions of GC IV. ${ }^{39}$

\footnotetext{
32 2009 SPO Art 7(d).

${ }_{33}^{33}$ Jamait Iscan v IDF Commander in Judea and Samaria, (1983) HCJ 393/82 PD 37(4) 785, para 33.

${ }^{34}$ D Kretzmer, The Occupation of Justice: The Supreme Court of Israel and the Occupied Territories (2002) 20.

352009 SPO, Art 8, originally SPO 1967 Art 11.

${ }^{36} 2009$ SPO, Art 153.

${ }^{37}$ Ibid, Art 86.

${ }^{38}$ Security Provisions Order (Amendment No 9) (Judea and Samaria) (Order No 144) 22 October 1967, Compilation of Proclamations, Orders and Appointments No 8, 303; for the Gaza Strip and Northern Sinai, 11 October; central Sinai, 31 December; Shlomo region, 29 November; Golan Heights, 3 October.

${ }^{39}$ By January 1968 the SPO itself had been amended ten times, and numerous other orders have
} 


\section{The military courts' self-perception as operating within a domestic legal order}

The law of occupation in general, and GC IV specifically, is rarely invoked before the military courts as a standard by which to review the validity of military orders. ${ }^{40}$ The few issues that have come up in this context include the competence of the military commander to establish the military courts; the military courts' jurisdiction over Israeli nationals; their jurisdiction with respect to offences defined under Jordanian law and to offences committed extraterritorially; the absence of a right of appeal; and the requirement to publish penal orders.

In only a handful of cases, early on in the occupation, have military courts acknowledged the law of occupation as the source of their authority. ${ }^{41}$ The prevalent view among the military courts is that their authority derives only from the SPO and is governed exclusively by the security legislation. ${ }^{42}$ The following

been adopted (and amended) on substantive and procedural issues. The new Art 35 was itself an alignment with GC IV Art 69. The Order was not put in line with GC IV completely. For example, the SPO was amended to allow consultative review of administrative detention, while GC IV Art 78 speaks of 'appeal'. On the recognition by the IDF of need to ensure that the applicable law-including Jordanian law-be put in line with GC IV, see the memoir lecture by Zvi Inbar (former Military Advocate General), 'The Military Advocate General's Office and the Administered Territories' (2002) 16 IDF Law Review 149, 152, describing preparations of legal instruments for occupation as early as 1963 (in Hebrew).

${ }^{40}$ The present discussion is limited to cases where the courts were willing to concede the applicability of GC IV to the territories as a matter of international law, either through an interpretation in this light of Article 2 or on the basis of Israel's unilateral commitment to comply with the humanitarian provisions of the Convention, eg Military Prosecutorv Bakkir (1969) 48 ILR 478, para 14(d).

${ }^{41}$ Eg Military Prosecutor $v$ Al Nasser Nablus 348/69, Selected Judgments of the Military Courts vol 1, 272, 277 (1969); Military Prosecutor v Bakhis and Others, Ramallah 144/68, Selected Judgments of the Military Courts vol 1, 371, 374 (1968); Abu Janem, above n 13, 140; see also Military Prosecutor $v$ Udda, Samaria 5708/01+5732/01, Selected Judgments of the Military Courts vol 13, 269, 277 (2002); Schwartz v IDF Commander, Appeals Commission (Judea and Samaria) 5/06 (31 October 2006, available on Nevo Database) 10; Drori, above n 24, 161.

${ }^{42}$ Eg Military Prosecutor $v$ Hamza, Hebron 185/67, Selected Judgments of the Military Courts vol 1, 497, 500 (1968); Military Prosecutor v Haroufa, Bethlehem 48/69 Selected Judgments of the Military Courts vol 1, 565, 567 (1970); Military Prosecutor v Zohair, Bethlehem 87/68, Selected Judgments of the Military Courts vol 1, para 9 (1968); Military Prosecutor v Al Nashash and Another, Ramallah 2015/92, Selected Judgments of the Military Courts vol 7, 365, 369 (undated); Radwan v Military Prosecutor and Military Prosecutor v Radwan, Single Judge Appeals Gaza 28/98 and 29/98, Selected Judgments of the Military Courts vol 11, 1, 7, 8 (1998); Military Prosecution v Naji (Abu Hamid), Beit El (available in Nevo Database) (23 September 2003) 2; Military Prosecutor v Salem, 
sections address the manner in which this view informs the military courts' stance regarding the applicability of international law, in particular GC IV, and their powers of judicial review of the security legislation in light of international law.

\subsection{Applicability of the law of occupation}

In a few cases the military courts acknowledged the direct applicability of international law. ${ }^{43}$ However, the military courts overwhelmingly adopt a dualist view, under which there are two distinct legal orders. One order is the internal law of the occupation regime, where the security legislation is the highest norm. The other order is the international legal one, where the security legislation is subordinate to customary and applicable conventional law. The military commander is accountable under this order only to his superiors or to international players-states or organisations. ${ }^{44}$ On the basis of this typology, the military courts have consistently applied dualist doctrines of reception, which condition the applicability of international law on it having been received in some form into the domestic orders. The military courts apply the doctrines under Israeli law: conventional law requires transformation through legislation, while customary law is automatically incorporated into the law of the land, but defers to conflicting explicit primary legislation, which in the occupied territory means the security legislation. ${ }^{45}$

In line with these doctrines, in a few cases the courts found that the Hague Regulations were invocable because they constituted customary international law. ${ }^{46}$ In some cases provisions of GC IV regarded as conventional law were found applicable on the ground that they had actually been transformed into the $\mathrm{SPO}^{47}$ or into the General Staff Orders. ${ }^{48}$ The replacement of SPO Article 35 was

(Judea and Samaria) (available in Nevo Database) (23 September 2003) 7; Military Prosecutor v. Haj Muhammad, Military Court of Appeals (Judea and Samaria) Appeal 1683/08 (available in Nevo Database) (23 October 2008) para 6.

${ }^{43}$ Eg Military Prosecutor $v$ Dan Wildman, Ramallah 160/68, Selected Judgments of the Military Courts vol 1, 377, paras 14-18 (1969); Military Prosecutorv Bakkir, above n 40, paras 14-15; Al Nasser, above n 41, 276-277; Udda, above n 41, 275.

${ }^{44}$ Hamza, above n 42, 500 .

${ }^{45}$ Salem, above n $42,9$.

${ }^{46}$ Military Prosecutor $v$ Shushan and Marciano. Ramat Hagolan 153/67, Selected Judgments of the Military Courts vol 1, 577, 582 (undated); Military Prosecutor $v$ Schoenbohm and Others, Bethlehem 1114/72, Selected Judgments of the Military Courts vol 3, 346, 351-352 (1972); Schwartz, above n $41,13$.

${ }^{47}$ Schwartz, above n 41, 14.

${ }^{48}$ Abu Janem, above n 13, 133-134; Schoenbohm, above n 46, 355. Staff orders are not invocable in 
interpreted by the military courts as an early transformation of GC IV, which the military commander later retracted. ${ }^{49}$ In most cases, however, the military courts held that since GC IV had not been transformed into the law of the territory, it was not invocable in the military courts. ${ }^{50}$

Furthermore, even when the courts were willing to consider, arguendo, that the law of occupation was applicable, they held that in case of conflict with security legislation, the latter prevails. ${ }^{51}$ An example is Abu Alaan (2010), where a question arose as to the interpretation of an order allowing forfeiture of property in the course of a criminal legal process. While the majority interpreted the order in a manner which it held to be in line with international law, ${ }^{52}$ the dissenting judge opined that the only possible interpretation of the order in light of its context was a different one, and one which he regarded as possibly contravening the law of occupation. He did not explore the matter further, since he held that the express military order enjoyed priority even if it violated international law. ${ }^{53}$

An exceptional case in this respect is $U d d a$ (2002), where the question arose whether the military commander was competent under Article 66 of GC IV to establish the military courts. The court stated that international law and the laws of armed conflict were 'super-norms' from which the security legislation derives its authority. Moreover, the court held that in case of direct conflict between the security legislation and customary international law (which it held Article 66 to be), the latter prevails. ${ }^{54}$

Mostly, however, the military courts have found that no conflict existed between GC IV or the Hague Regulations and specific provisions of the security legislation. This is true regardless of whether they considered that GC IV had no applicability and only addressed its status in obiter dicta; ${ }^{55}$ where the status

military courts.

${ }^{49}$ Military Prosecutor v Al Takruri, Hebron 230/70, Selected Judgments of the Military Courts vol 2, 137, 148 (1971). The court nonetheless held that GC IV might have been transformed into the security legislation by other means; Salem, above n 42, 10 .

${ }^{50}$ Eg Hawaja $v$ Military Prosecutor, Ramalllah MiscReq212/92, Selected Judgments of the Military Courts vol 7, 350, 355 (1992); Zohair, above 42, para 9; Schoenbohm, above n 46, 354-355; Military Prosecutor v Atoun, Judea 3831/06 (decision) (available on Nevo database) (12 September 2006).

${ }^{51}$ Salem, above n 42, 8-9.

${ }^{52}$ Military Prosecutor v Abu Alaan, Military Court of Appeals (Judea and Samaria) 3443/09 (available on Nevo database), President Mishnayot, 19 (2010).

${ }^{53}$ Ibid, Vice-President Benichou 32.

${ }^{54}$ Udda, above n 41, 275, 277.

${ }^{55}$ Haroufa, above $\mathrm{n}$ 42, 567: security legislation amending local law to penalize bribery was in line with GC IV Art 64; Zohair, above n 42, para 12, 20: publication of a military order in Arabic through village leaders and posters in the public domain is in compliance with GC IV Art 65, as 
of GC IV was not even mentioned; ${ }^{56}$ or where the superiority of GC IV was acknowledged. ${ }^{57}$ An exception was Al Takruri (1971), where the court found that the order granting the military courts jurisdiction over offences under local law (Jordanian law) $^{58}$ was prima facie contrary to the principles of Article 64 of GC IV. The court noted that, following the annulment of Article 35 of the SPO, GC IV was no longer formally binding upon it, but that military courts had in the three years since the annulment of Article 35 never relied on the annulment. ${ }^{59}$ However, the court avoided deciding which norm takes priority, and instead referred the matter to a bench of three judges. ${ }^{60}$ The latter eventually acquitted the defendant on the ground that his specific conduct did not constitute an offence under Jordanian law, rendering the conflict of norms question moot. ${ }^{61}$

Regardless of the classification of specific norms as customary or as conventional law, and regardless of the findings on whether particular military orders

is prosecution for an offence committed after this publication, regardless of the date of entry into force of the order, which may have been prior to the publication; Al Nashash, above n 42, 370; Hawaja, above n 50, 355: GC IV does not preclude military courts from trying under local law; Hamza, above $\mathrm{n} 42,500$, means of publication did not violate the requirements of nullum crimen sine lege; Schoenbohm, above n 46, regarding prosecutions of Israeli nationals before military courts, and compatibility of security legislation prohibiting incitement and hostile propaganda with GC IV Article 27.

${ }^{56}$ Military Prosecutor v Jabber Hebron 57/69 Selected Judgments of the Military Courts vol 1, 515 (1969): GC IV allows imposition of capital punishment; Military Prosecutor $v$ Ya'i and Another Gaza 1410/74, Selected Judgments of the Military Courts vol 4, 25, 27 (1974): compatibility with GC IV Article 73 where there is no right of appeal on decisions of the military courts; Ajuri v Military Commander, Judea and Samaria Appeals Commission 3/02, Selected Cases of the Military Courts in the West Bank 14 (Part 1) 406 (2002), Appeals Commission set up under Art 85(c) of the 1970 SPO (Order 378); Military Prosecutor v Al Khatib, Ramallah 196/67, Selected Judgments of the Military Courts vol 1, 363, 364-365 (undated); Al Haj and Others v Military Prosecutor, Gaza MiscReq 452/93, Selected Judgments of the Military Courts vol 7, 539 para 10(c) (1993); Schoenbohm, above n 46, 354-56.

${ }^{57}$ Bakkir, above $\mathrm{n} \mathrm{40,} \mathrm{para} \mathrm{14:} \mathrm{the} \mathrm{military} \mathrm{commander} \mathrm{cannot} \mathrm{grant} \mathrm{the} \mathrm{military} \mathrm{courts}$ extraterritorial jurisdiction without an express provision; Wildman, above $\mathrm{n}$ 43, para 17: the provisions invoked in the charge sheet do not allow extraterritorial jurisdiction, which might be in violation of general principles of international law, embodies in GC IV Art 67; Al Nasser, above $\mathrm{n} 41$ : the military court is not bound by Jordanian criminal procedural law; Udda, above $\mathrm{n}$ 41, 276-77: validity of the establishment of the military courts.

58 Order regarding Jurisdiction in Criminal offences (No 30) 1967, later incorporated in 2009 SPO, Article 10(a).

59 The court noted that some GC IV provisions may have binding effect through its incorporation in staff orders, but refused to rely on this and noted that no court had previously based a ruling on the applicability of GC IV solely on this incorporation; Al Takruri, above n 49, 151-153.

${ }^{60}$ Ibid, 155.

${ }^{61}$ Ibid, 156-157. 
conflicted with these norms, all these analyses are misconceived in the very resort to doctrines of reception. They draw on, and are clearly influenced by, the consistent application of the doctrines of reception by the HCJ with respect to the applicability of the law of occupation in petitions submitted to it. However, the HCJ and the military courts operate in different types of legal orders. The HCJ derives its authority from Israeli constitutional law and conducts its review of the military government in the occupied territories in light of Israeli law. Accordingly, it must reconcile differences between Israeli law and the international legal order before international law is enforceable. In contrast, the military courts operate not within a domestic legal order but directly within the international one. The reference to reception by the military courts is therefore unwarranted. As exceptionally noted by one panel, the military commander cannot cut off the branch it sits on. ${ }^{62}$

\subsection{Hierarchical status of the law of occupation vis-à-vis the security legislation}

The power of military courts to review the military commander's legislative orders $^{63}$ is implied in GC IV Article 67, which stipulates that '[t]he courts shall apply only those provisions of law which were applicable prior to the offence, and which are in accordance with general principles of law.... This provision requires the military courts to apply certain principles irrespective of any contrary security legislation. ${ }^{64}$ Military courts have on rare occasions mentioned this provision, but have not regarded it as an independent source for their authority. For example, in Zohair (1968) the court held that a defendant could not challenge the validity of security legislation but held that the court itself had an inherent power to refuse to implement an order of the military commander if the order patently violated the 'general principles' of international law mentioned in Article $67 .^{65}$ While the court's conclusion on its power of review was correct, it is nothing short of incredible that the court deduced the relevance of Article 67 by analogy from the applicability-itself by analogy!-of Article 67 to domestic courts of the

\footnotetext{
${ }^{62}$ Schwartz, above $\mathrm{n} 41,14$.

${ }^{63}$ As opposed, in this case, to administrative orders against individuals.

${ }^{64}$ Von Glahn, above n 16, 117.

${ }^{65}$ Zohair, above n 42, para 8. See also Salem, above n 42, 13. In view of the courts' subsequent refusal to rely on GC IV on the ground that it had not been transformed into the law applicable in the court, it is not clear how they could rely on Article 67. Perhaps an 'inherent power' needs no transformation, but the court said nothing to this effect. The use of 'inherent power' in this context is odd, since such power is by definition not provided by the law.
} 
occupied territory (i.e. Jordanian or Palestinian courts), even though Article 67 applies directly to military courts of the occupant. ${ }^{66}$

Ostensibly, if the courts hold that international law does not constitute part of the legal order of the occupation, the issue of its hierarchical status vis-à-vis the security legislation does not arise at all. Indeed, military courts have for the most part held that they have no power to hear claims against the validity of the security legislation, except where the SPO itself expressly provides for such power. This recalls the position held by the Israeli HCJ prior to the adoption of the constitutional Basic Laws, namely that it could not review primary legislation. It is indeed no coincidence that whatever willingness the military courts have shown towards reviewing security legislation began in the mid 1990s, following the constitutionalisation of Israeli law. Without the HCJ ruling that a court may declare a law which was incompatible with 1992 Basic Law: Human Dignity and Freedom unconstitutional and invalid because of unconstitutionality, ${ }^{67}$ it is unlikely that the military courts would have made even the small advances that they have. ${ }^{68}$

Yet there is still strong opposition among the military courts to the review of the security legislation in light of international law. An extremely forceful example of the security legislation's immunity from review is Haj Muhammad (2008). The defendant was charged with two offences, one of which was manslaughter of a person whose identity was unknown. The crime took place in an area designated under the Interim Agreement as Area A, where, according to the Interim Agreement, jurisdiction over criminal matters lies with the Palestinian Authority. However, as noted earlier, the SPO preserves the jurisdiction of the military courts over offences committed in Area A which harm or are intended to harm the security of the West Bank. The military courts have interpreted this provision as extending to offences against Israelis.

\footnotetext{
${ }^{66}$ According to scholarly literature, local courts of the occupied territory may refuse to apply law of the military government that is patently beyond its power under international law; see $\mathrm{M}$ Greenspan, The Modern Law of Land Warfare (1959) 246, cited in Zohair, above n 42, para 10. In practice, local courts do not take this liberty, out of concern for their self-preservation; see E Benvenisti, The International Law of Occupation (2 ${ }^{\text {nd }}$ ed 2012) 324. Nor would any occupant subject itself to rulings of local courts. In this last respect, military courts are significantly more powerful than local courts.

${ }^{67}$ United Mizrahi Bank Ltd $v$ Midal Cooperative Village and Others, CivApp 6821/93 PD 49(4) 221, Opinion of Justice Shamgar, para 60 (1995), official translation at <http://elyon1.court.gov.il/files_eng/93/210/068/z01/93068210.z01.pdf> [accessed 04 May 2013].

${ }^{68}$ View expressed by military court judge; interview on file with author.
} 
Another enactment issued by the military commander in June 2007 declares that the military courts have jurisdiction when the victim is unidentifiable, if there is 'evidence that supports the possibility that he or she was Israeli. ${ }^{69}$ This notice empowers the military court to convict a person even if not all elements of the crime had been proven beyond reasonable doubt. The Military Court of Appeal expressed its discomfort with this contravention of 'fundamental criminal legal principles', but held that since its own authority derives strictly from the SPO, it must abide by the military commander's notice. ${ }^{70}$ Importantly, at issue was not merely the establishing of jurisdiction (the requisite facts for which, according to some views, need not be proven beyond reasonable doubt). Since the security legislation is only applicable in the military courts and not in local courts (where jurisdiction would otherwise lie), the choice of jurisdiction brings about the application of particular substantive law-the security legislation-and thus potential conviction for offences that are not necessarily punishable otherwise. If this is done on the basis of insufficiently proven factual criteria, it violates the principle nullum crimen sine lege. ${ }^{71}$

The resistance to judicial review in light of GC IV, like the resistance to the applicability of the law of occupation, evidences the military courts' self-perception as part of a separate domestic legal order. The objections expressed by the courts to judicial review of primary legislation under GC IV are almost without exception grounded in domestic constitutional principles, especially those which apply in Israeli law. One objection is that unlike the Israeli parliament, which opted to limit its legislative power by adopting constitutional norms, the military commander had not chosen to limit his powers, or, if he had limited them by adopting SPO Article 35 in its original formulation, has since retracted the limitation. ${ }^{72}$ This reasoning mistakenly assumes that it is for the military commander to determine his own authority. Moreover, the analogy from Israeli law is incorrect, since the constitutional norms of Israeli law are regarded as having been adopted by parliament acting not in its legislative capacity but as the constitutional assembly of the state; ${ }^{73}$ this is partly

\footnotetext{
${ }^{69}$ Cited in Haj Muhammad, above n 42, para 12.

${ }^{70} \mathrm{Ibid}$, paras 6, 14 .

${ }^{71}$ The expansion of the court's jurisdiction is not, in itself, a violation of general international law or GC IV but only of the Interim Agreement. Consequently, even without any proof of the victim's identity, the law of occupation recognizes the court's jurisdiction. However, if the security legislation is regarded as the exclusive source for the court's jurisdiction, the law of occupation cannot be relied upon to expand that jurisdiction.

${ }^{72}$ Salem, above n 42, 7-8.

${ }^{73}$ United Mizrahi Bank, above n 67.
} 
in acknowledgment that the authority of constitutional law cannot depend on the legislator's consent to be bound by it. With respect to the legal order of the occupation there is no need for such legal construct, since the source of international law (the community of states) is truly distinct from the source of the security legislation (the military commander).

It has been argued that the military courts have no power of review because GC IV does not have the appearance of a constitution. ${ }^{74}$ To this one panel has responded that basic principles that do resemble a constitution can be found in customary international law. ${ }^{75}$ However, it is interesting to note the common expectation that normative superiority under international law take a form that is similar to that of domestic constitutional law. This expectation reflects, as do the other arguments, a mistaken, domestic, view of the normative framework.

Another reservation to review is evident in the debate whether the military courts are the appropriate venue for judicial review (if such is possible). In Salem (2003) the court held that even if the compatibility of the military commander's orders with international law was reviewable, military courts are not necessarily the institutions empowered to conduct the constitutional review, as this power may be reserved for the HCJ. ${ }^{76}$ A different view was held in Udda (2002), namely that not only the HCJ but also the military courts may declare a piece of security legislation incompatible with international law. ${ }^{77}$ This controversy echoes a similar one that had arisen earlier within domestic Israeli law, on whether constitutional review was possible in all courts or only in the HCJ. The very engagement with the question of which court is empowered to conduct a constitutional review assumes that there are different types of courts. Within the military legal order, however, there is no such variety. The proposition that a 'constitutional' challenge in light of international law ought to be brought before the HCJ raises a separate question, discussed below, namely whether the military courts can legitimately exempt themselves from enforcing international law on the ground that the HCJ can do so. Moreover, it is noteworthy that the military courts have been open to the view that the military government is subject to review under Israeli constitutional law since the latter applies to all organs of the state of Israel, regardless of where they operate, ${ }^{78}$ while rejecting

\footnotetext{
${ }^{74}$ Salem, above n $42,8$.

${ }^{75}$ Schwartz, above n 41, 13.

${ }^{76}$ Salem, above $\mathrm{n} 42,7$.

${ }^{77}$ Udda, above n 41, 275.

${ }^{78}$ Basic Law: Human Dignity and Freedom, SH 5752 no. 1391, 150, Article 11; Y Ronen, 'Applicability of Basic Law: Human Dignity and Freedom in the West Bank' (2013) 46 Israel L Rev 135.
} 
review under customary international law, even though the applicability of the customary law of occupation to all military organs operating in the West Bank is far better established under Israeli jurisprudence than the applicability of Israeli constitutional law, such as Basic Law: Human Dignity and Freedom.

\section{Digging in their heels}

The refusal of the military courts to apply the law of occupation, let alone employ it as a standard of review, deprives the residents of the occupied territory of the protection of international law. Such an approach is always problematic from an international human rights legal perspective; in the case of occupation it is particularly disturbing. In independent, democratic states, political conventions and custom protect against abuse of power by the government, as do legal mechanisms, both substantive (a bill of rights) and procedural (constitutional review). ${ }^{79}$ In occupied territory the military government is not representative of the population, and is not accountable to the population through the political process. $^{80}$ It is precisely for this reason that Article 67 of GC IV places an obligation directly on the courts of the occupant, irrespective of the legislative and executive acts of the military commander. If the military courts refuse to apply international law and to accord it superiority over the security legislation, they renege on their role as protectors of the population and leave it dependent on the benevolence of a hostile government.

However, according to the military courts, the non-enforceability of international law is offset in practice by two elements. One is that the military courts interpret the security legislation by reference to Israeli law, as a proxy for compliance with international human rights law. The other is that while international law is not enforceable in the military courts, it can be enforced in the HCJ. ${ }^{81}$ The present section argues that these responses are themselves premised on a misperception of the courts as domestic institutions of a democratic state and do not adequately address the shortfall in protection under international law.

\footnotetext{
${ }^{79}$ M Loughlin, 'Rights, Democracy, and Law', in T Campbell, K D Ewing \& A Tomkins (eds), Sceptical Essays on Human Rights (2001) 42.

${ }^{80}$ Jamait Iscan, above n 33, para 23; Gaza Coast Regional Council and Others v Israeli Knesset, HCJ 1661/05, PD 59(4) 481, para 9 (2005).

${ }^{81}$ These stances are implicit in many judgments, but have been stated explicitly in interviews with the author.
} 


\subsection{Israeli domestic law as proxy for compliance with international law}

Israeli law plays a dominant role in the military courts. The security legislation was originally modelled on military law, but has gradually evolved with the conscious instigation and encouragement of the courts to emulate Israeli civilian criminal law. As noted above, with respect to procedure and evidence, this emulation is entrenched in the SPO itself. It has also expanded to substantive criminal law. The military courts have repeatedly emphasized that they are neither bound by Israeli criminal law ${ }^{82}$ nor do they apply it directly, but they draw on it in interpreting the security legislation. Israeli law must not be duplicated blindly but must be examined in light of the difference in circumstances prevailing in Israel and in the occupied territories; but emulation constitutes the default prescription, divergence from which must be clearly justified. ${ }^{83}$

Although the reference to Israeli law is hardly surprising as a matter of convenience, courts have on more than one occasion justified it on normative grounds, namely that Israeli law is a best practice guide, both for administration of justice ${ }^{84}$ and as a mechanism to balance the maintenance of security against protection of defendants' rights. ${ }^{85}$ Indeed, the civilianisation of the law has been hailed for replacing draconian arrangements appropriate for a state of exception with norms applicable in a state of normalcy. ${ }^{86}$

The proposition that the qualified emulation of domestic law is an adequate alternative to direct application of international law raises a number of difficul-

${ }^{82}$ Military Prosecutor v. Abu Saleem, Military Court of Appeals (Judea and Samaria), Detention Appeal 157/00, Selected Judgments of the Military Courts vol 11, 217 (2000).

${ }^{83}$ Military Prosecutor v Abu Sneina, Military Court of Appeals (Judea and Samaria) 353/03 (available on Nevo Database), Judge Friedman para 18 (4 April 2004).

${ }^{84}$ Casey and Others $v$ Military Prosecutor, Military Court of Appeals (Judea and Samaria) 22/95 (available in Nevo database) 8 (13 March 1995); Military Prosecutor v Bayumi, Ramallah 3027/83, Selected Judgments of the Military Courts vol 6(2), 463, para 11(d) (1983).

${ }^{85}$ Abu Al Hija v Military Prosecutor, Military Court of Appeals (Judea and Samaria) 1643/05 (available in Nevo database) 43, with examples (7 September 2011). In addition, use of the same legal system as that which is applicable in Israel enables the maintenance of equality among defendants when criminal proceedings relating to certain events are conducted simultaneously in the military courts and in civilian courts within Israel: Abu Sneina, above n 83, Judge Gordon, 10. Dinstein has argued that emulation of the occupants' national law is prima facie evidence of the genuineness of the occupant's concern for the welfare of the population. Y Dinstein, The International Law of Belligerent Occupation (2009) 121. This litmus test has not been applied in the case law.

${ }^{86}$ Benichou, above n 4, 325. 
ties. First, in practice the military courts' rejection of claims grounded in international law is not contingent on the applicability of law similar to that of Israel, but follows a principled stance on the inapplicability of international law. Second, Israeli law itself is not necessarily compliant with international human rights law. ${ }^{87}$ Admittedly, the military courts must not apply Israeli law blindly. However, given the general policy of emulation, it would be difficult for a military court to disapprove of a norm that is sanctioned under Israeli law, especially on the ground that it violates international law, since such a step would challenge not only substantive Israeli law but also the state's juridical institutions. Third, and most importantly, the use of domestic standards of a democratic state as proxy for compliance with the law of occupation disregards the inherent factual and normative differences between the two regimes.

An example of a pertinent factual difference concerns familiarity with the law and its language: Article 71 of GC IV provides that accused persons 'shall be promptly informed, in writing, in a language which they understand, of the particulars of the charges preferred against them'. The SPO is silent on translation, while Israeli procedural law only provides for translation of proceedings but not of documents. ${ }^{88}$ In the West Bank, only the security legislation is published in Arabic. The MAG has undertaken to translate all charge sheets into Arabic, but only following a petition to the HCJ. ${ }^{89}$ The paucity of regulation in domestic law is natural. The laws of an independent state on the right to counsel are premised on all professional participants in the legal process-judges, prosecutors and defence counsel-being equally versed in the law of the land. But under an occupation regime, there is an enormous disparity in legal expertise, between the court and prosecution on the one hand, and the defence on the other. Standards that are appropriate for ensuring equality of arms in a democratic state are therefore insufficient in occupied territory. Heavy reliance on the domestic law of the occupant risks exacerbating the already inherent inequality of arms stemming from the fact that the court is an organ of the same regime as the prosecution, and compromising the right to facilities

\footnotetext{
${ }^{87}$ See, e.g., Internment of Unlawful Combatants Law, 5762-2002, SH 5762 no. 1834, 192, Article 7, establishing a presumption of individual threat contrary to the Emergency Powers (Detention) Law, 5739-1979, SH 7739 no. 930, which requires proof of the same. See also discussion in $A v$ State of Israel, CrimApp 6659/06 (available in Nevo database) (11 June 2008), para 18-24, available in English at <http://elyon1.court.gov.il/files_eng/06/590/066/n04/06066590.n04.pdf> [accessed 04 May 2013].

${ }^{88}$ Criminal Procedure Law [Consolidated Version] 5742-1982 (Israel) Art 140.

${ }^{89}$ Al Alarj v IDF Commander in the Area, HCJ 2775/11 (available in Nevo database) (3 February 2013).
} 
to ensure effective defence. ${ }^{90}$ The right to a fair trial ${ }^{91}$ should be interpreted as placing a much heavier burden on the military legal system in comparison with the domestic system. This might include measures that are largely irrelevant in independent states, such as an obligation to translate legislation, case documents and jurisprudence to the language of the territory. ${ }^{92}$ Judges of the military courts dismiss the problem of translation as theoretical, on the ground that, in practice, most defence lawyers are Hebrew speakers and defendants routinely waive the right to have the charge sheets translated into Arabic. ${ }^{93}$ They fail to note that defendants waive this right because insisting on it would prolong the trial. Application of quasi-domestic law, regardless of how modern and progressive, without addressing these idiosyncratic problems, merely obfuscates flaws in the process.

A blatant expression of the failure to appreciate the inequality of arms is the explanation by the military court of the recourse to Israeli law, inter alia on the ground that 'from the personal perspective, all those involved, whether in legislation or in adjudication, have been raised and educated in the Israeli system. It is only natural that they turn to the sources of law familiar to them.94 The challenge to the defendant is not even mentioned.

An example of a normative difference concerns periods of detention: the maximum period of detention before the end of trial under the SPO are longer than those under Israeli law. ${ }^{95}$ This is contrary to the international standard, since Article 71 of GC IV requires that defendants be brought to trial 'as rapidly as possible', a stricter standard than the 'reasonable time' standard under international human rights law, which governs domestic legislation. ${ }^{96} \mathrm{~A}$ domestic standard is tailored to a democratic society, where limitations on rights

${ }^{90} \mathrm{~S}$ Ben Natan, 'The Honey Trap: The application of Israeli law in the military courts of the Occupied Palestinian territories', LLM Thesis submitted to the University of Oxford (2010) (on file with the author).

${ }^{91}$ GC IV Arts 65, 71, 72.

${ }^{92}$ Ben Natan, above n 90, 40-41.

${ }^{93}$ G E Bisharat, 'Courting justice? Legitimation in lawyering under Israeli occupation' (1995) 20 Law \& Social Inquiry 349, 362; Ben Natan, above n 90, 8. It is also a result of Palestinian lawyers boycotting the Israeli system.

${ }^{94}$ Abu Sneina, above n 83, Judge Gordon, 9-10.

${ }^{95} 2009$ SPO (as amended) Art 44 (18 months and extensions of six months for adult defendants accused of security offences; for defendants charged with non-security offences one year and extensions of six months for adults and three months for minors; Criminal Procedure Law (Detention Powers) 5756-1996 (Israel) Arts 61-62 (nine months and extensions of 90 days).

${ }^{96}$ International Covenant on Civil and Political Rights, 16 December 1966, 999 UNTS 171, Art 9(3) (ICCPR); M Nowak, U.N. Covenant on Civil and Political Rights: CCPR Commentary (1993) 233. 
are prima facie deemed to be in pursuit of legitimate aims and proportionate. ${ }^{97}$ Such considerations deriving from the social contract and the fundamental (although not blind) trust in the good faith of government do not prevail in occupied territory. ${ }^{98}$ Maximum periods of pre-trial detention must therefore be shorter than in the domestic order. Yet the matter does not stop there: at issue is also the discretion of the courts in approving initial and extended detention. In the absence of political mechanisms to hold the government in check, the judiciary bears a heavier burden to shield the population from potential abuse of power. The judges of the military courts regard themselves as having been strong and successful proponents of significantly shortening detention periods under the security legislation, to bring them into greater proximity with Israeli law. However, the goal of the military courts should be to limit detention periods even beyond what is permissible within Israel. The same rationale applies to other restrictions on human rights implicated in the criminal process.

This proposition appears to defy the conventional wisdom that situations of armed conflict may justify greater limitations on, or derogations from, rights. ${ }^{99}$ It is important to note, however, that while the existence of conflict might justify greater restrictions on the population in order to maintain security, there is nothing inherent to conflict that a priori justifies compromising procedural rights once a person is in the hands of law enforcement agencies. This is particularly true when hostilities are no longer taking place, as is generally the case under occupation.

The military courts regularly acknowledge the need to take the circumstances of occupation into account, but ironically these are invoked to justify greater limitations on rights. One oft-cited factor is the security threat, as grounds for more severe restrictions on liberty in comparison with Israeli law. ${ }^{100}$ Another diversion from Israeli law was the rejection of the Israeli Kinsey doctrine, according to which defendants may only testify against co-perpetrators after the conclusion of their own trials, when they no longer have an incentive to offer falsely-incriminating testimony. ${ }^{101}$ In Badarna the military court decided

\footnotetext{
${ }^{97}$ Benvenisti, above n 66, citing Mahoney, 'Section 1: Perceived Principles and PremisesMarvellous Richness of Diversity or Invidious Cultural Relativism?’ (1998)19 HRLJ 1.

${ }^{98}$ Bisharat, above $n$ 93, 381.

${ }^{99}$ National security is a legitimate ground for limiting rights, refs; armed conflict may also constitute a public emergency as defined in ICCPR Art 4.

${ }^{100}$ Ben Natan, above n 90, 38.

${ }^{101}$ Kinsey $v$ The State of Israel, CrimApp 194/75 PD 30(2) 477(1976). This doctrine was eventually also rejected within Israel in The State of Israel v the District Court of Beer-Sheva, HCJ 11339/05 (8
} 
not to apply the Israeli doctrine, arguing that it was irrelevant since Palestinian defendants never incriminate their partners in crime before an Israeli court. ${ }^{102}$

One might argue that especially in situations of hostility, emulation of domestic law has the advantage of richness, precision and detail, ${ }^{103}$ which remove a large measure of discretion from the hands of executive and even judicial institutions whose interests and aspirations are frequently in opposition to those of the population. ${ }^{104}$ However, precision is not a virtue in itself: detailed rules formulated for a democratic, politically and legally accountable regime may be insufficiently protective in a regime of occupation. The present analysis does not suggest that drawing on domestic law-in particular Israeli law-is injudicious. Clearly it is advisable to apply a coherent system which is highly developed and dynamic. ${ }^{105}$ Yet emulation of norms and regimes must follow from a careful examination of their transferability in light of pertinent differences. International law does not offer specific guidelines for such an examination, but it does highlight that at issue are power relations that are not sovereign and democratic.

\subsection{The $\mathrm{HCJ}$ as a forum for challenging violations of international law}

The other response to criticism that the military courts are not receptive to challenges of incompatibility with international law is that defendants can and do bring claims to this effect before the HCJ. Since the security legislation is often modelled on Israeli law, challenges are sometimes brought against the constitutionality of the original Israeli law. If the challenge succeeds and the law within Israel is amended, the change is soon emulated with respect to the security legislation, ${ }^{106}$ through jurisprudence or military enactments.

October 2006), and is no longer part of Israeli law.

${ }^{102}$ Badarna v Military Prosecutor, Appeal (Judea and Samaria) 282/94 (available on Nevo Database).

${ }^{103}$ Abu Sneina, above n 83, Judge Gordon, 10; Benichou, above n 1, 326.

${ }^{104} \mathrm{~A}$ Cohen, 'Rules and Standards in the Application of International Humanitarian Law' (2008) 40 Israel L Rev 41, 60; G Harpaz and Y Shany, 'The Israeli Supreme Court and the Incremental Expansion of the Scope of Discretion Under Belligerent Occupation Law' (2010) 43 Israel L Rev $514,546$.

${ }^{105}$ One might nevertheless query whether the coherent system needs to be that of the occupant; Ben Natan, above n 90, 44. Following the Second World War, different approaches were adopted to this matter: The US, for example, held that it was appropriate to approximate the military legal order in Germany to local law, so that it be familiar to the population; Greenspan, above n 66, 259. This probably does not eliminate the imbalance but possibly reduces it.

${ }^{106}$ See, e.g., CrimReqMisc 8823/07, A v State of Israel, 11 February 2010 (available on Nevo Database), which concerned a challenge (under Israeli constitutional law) to a legal provision allowing 
Enforcement of international law by the HCJ may appear advantageous to defendants since a civilian court may have a more rights-protective ethos than an organ of military government. Moreover, in the HCJ the security legislation is regarded as secondary legislation, and is therefore subject to administrative review in addition to the constitutional review under which incompatibility with international law would fall.

However, the HCJ is a domestic court, operating within a non-criminal legal order. Its capacity to second-guess the balance struck by the executive is limited because of its status as an instance of review, lack of expertise and democratic deficit. ${ }^{107}$ As a result, it does not substitute its own discretion for that of the military commander, but only examines whether the commander acted within the limits of his authority and within the margin of reasonable conduct. $^{108}$ The military courts, being organs of the executive itself, need not exercise the same restraint in overseeing the military commander; and as trial instances their scrutiny can and ought to be much more stringent than that of the HCJ. ${ }^{109}$ In practice, military judges do not articulate reliance on their personal acquaintance with the military system, although in one early case a judge stated that since acquaintance with military material is a prerequisite for the authority to judge, judges must not dissociate themselves from their knowledge as military personnel. ${ }^{110}$ In the event, the judge relied on his personal knowledge to reject the defendant's claim that a particular order had been given retroactive effect.

extension in absentia of detention of persons suspected of a security offence. The provision was declared unconstitutional. Its mirror provision in the security legislation was subsequently amended.

${ }^{107}$ Harpaz and Shany, above n 104, 546.

${ }^{108}$ See, e.g., Ajuri v IDF Commander in West Bank, HCJ 7015/02 PD 56(6) 352, para. 29 (2002), official translation at <http://elyon1.court.gov.il/Files_ENG/02/150/070/A15/02070150.A15.pdf> [accessed 04 May 2013]; Abu Safiyeh $v$ Minister of Defense, HCJ 2150/07 (available in Nevo database), Justice Vogelman para. 27 (29 December 2009), official translation at <http://elyon1.court.gov.il/files_eng/07/500/021/m19/07021500.m19.pdf> [accessed 04 May 2013]; Bethlehem Municipality $v$ State of Israel, HCJ 1890/03 PD 59(4) 736, Justice Beinisch, para 19 (2005), official translation at <http://elyon1.court.gov.il/Files_ENG/03/900/018/N24/03018900.n24.pdf> [accessed 04 May 2013].

${ }^{109}$ But see Mamduch Avra v Military Commander in Judea and Samaria, HCJ 317/13 (available on Nevo database), para 14 (27 January 2013), in which the HCJ criticized the military court for not exercising greater control of the military prosecution.

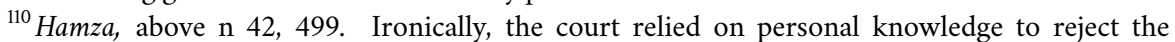
defendant's claim that he was convicted on the basis of retroactive legislation, stating that the order in question had been made known to the population prior to the formal publication in the Compilation of Proclamations, Orders and Appointments. 
In addition, the expectation that the HCJ apply to petitions of defendants from occupied territory the same rights-protective approach that it exercises in domestic disputes is debatable, for example due to the adversity of the petitioners' interests to the society to which the court is committed. ${ }^{111}$ It is not that the military courts are immune to these biases. However, their bias is openly acknowledged, and international law governs their conduct precisely in order to temper the effect of that inherent bias. Surrender of the responsibility to enforce international law to a domestic court is therefore a dereliction of duty. Ironically, the problem is further exacerbated by the fact that the HCJ increasingly invokes international human rights law in its West Bank-related judgments. This apparently welcome move operates to the detriment of the local population, since the HCJ applies it to derogate from non-derogable rules of the law of occupation. ${ }^{112}$

\section{Conclusions}

The Israeli experience is unique: it is the only instance in which an occupant has acknowledged its status as such and has established a military court system that is subject to international legal norms. It is unique also in its factual circumstances: a prolonged occupation in which criminal proceedings concern a wide range of conduct, long after active hostilities have ended; and contiguity with the territory of the occupant, which renders domestic legal institutions accessible, physically and procedurally. Under these circumstances, the temptation to downplay the courts' character as military institutions trying civilians, with the negative connotation that the existence of such institutions carries, is understandable. However, the military courts operate within a carefully crafted legal order, which aims to mitigate the inherent biases of a military system through the protection of international law. Failure to appreciate the particular position of the courts within this order risks resulting in the removal of protection to defendants without adequate substitutes.

The military courts in the West Bank consider themselves to be operating within a dualist legal order, in which the security legislation constitutes the highest norm. They therefore deny the primacy of the law of occupation over

\footnotetext{
${ }^{111}$ Kretzmer, above n 34; Y Ronen, Silent Enim Leges Inter Arma-but Beware of Background Noises: Domestic Courts as Agents of Development of the Laws of Armed Conflict' (2013) 26 Leiden J of Int'l L 599, 610.

${ }^{112}$ A M Gross, 'Human Proportions: Are Human Rights the Emperor's New Clothes of the International Law of Occupation', (2007) 18 EJIL 1.
} 
the security legislation, and as a standard for their own review of executive and legislative conduct of the military commander. Instead, the military courts rely heavily on quasi-Israeli law and defer to the HCJ as primary enforcer of international law. However, both measures are merely a continuation of the dualist perspective, and do not provide an adequate substitute for the application of the law of occupation by the military courts themselves. Moreover, the emulation of domestic law applicable in a democratic regime has the aura of normalcy, which obfuscates the exceptionality of occupation.

The intention of the courts is noble. They emulate Israeli law because it seems to offer a balancing mechanism between the needs of law enforcement and human rights. If the alternative were a legal vacuum, this approach would be beyond reproach. However, there is no legal vacuum, since international law is directly applicable. It may be less developed than domestic law, but it offers the appropriate framework for balancing law enforcement against human rights in an occupied territory. Applying international law directly rather than quasi-domestic law is likely to make the military courts unpopular with the military government. But their primary duty is to guarantee defendants their right to fair trial and other rights relating to the criminal process. 